\title{
HELPING GENERAL NURSES OVERCOME NEGATIVE PERCEPTIONS OF MENTALLY ILL PEOPLE
}

\author{
Nicholas G. Procter, RN RPN BA Grad Dip Adult Ed \\ Lecturer: Faculty of Nursing \\ University of South Australia
}

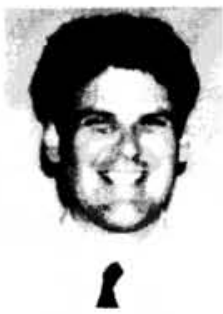

\begin{abstract}
Psychiatric-mental health care throughout the modern world is on the move. This article describes the role of the mental health component of a general nurse's education as one that engenders positive attitudes towards the mentally ill of a kind that seems likely to persist. With the support of a specially devised program supported by reflective practice and clinical field experience, the author argues that the expert guidance of clinical and academic staff can help nurses who do not primarily work with the mentally ill, better assess, relate to, and comfort such people. Such preparation is an important means to prepare general nurses beyond their traditional setting, as a feature of care for all practice settings.
\end{abstract}

\section{OPSOMMING}

Psigiatriese geestesgesondheidsorg is dinamies regdeur die moderne wêreld. Hierdie artikel beskryf die rol van die geestesgesondheidskomponent van ' $n$ algemene verpleegkundige se onderrig as een wat positiewe houdings teenoor geestesongesonde individue aanmoedig wat blykbaar volhoubaar is. Met die ondersteuning van ' $n$ spesiaal ontwerpte program ondersteun deur reflektiewe praktyk en kliniese ondervinding kan die deskundige leiding van kliniese en akademiese personeel verpleegkundiges help, wat nie hoofsaaklik werk met geestesgesongestelde individue nie, om sulke mense beter te beraam, in verhouding mee te tree en te troos. Sulke voorbereidings is 'n belangrike wyse om algemene verpleegkundiges voor te berei verder as hulle tradisionele opset, as ' $n$ aspek van sorg vir alle praktyk opsette.

\section{NEW DIRECTIONS IN PSYCHIATRIC CARE}

Out of sight and out of mind in purpose built institutions has been the way society has historically dealt with the mentally ill. We are now seeing a departure from the majority of these structures with recent changes in mental health care and treatment. These changes aim to re-focus patterns of care to a community orientated approach. This means that opportunities have emerged for the health and helping professions to free their vision of the way that treatment is given to people with mental health problems, as well as the care and comfort of their families. In the United States (Macias et al, 1994), Australia (National Mental Health Policy, 1992) and the United Kingdom (Lear, 1993; Mc Crone et al, 1994), for instance, changes in government health policy have brought the need for greater emphasis to be placed on psychiatric treatment in the community.

Schools of nursing throughout the world have an obligation to the mentally ill to ensure that specialist mental health placements continue during general nurse education. In meeting this challenge, educational institutions must give considerable attention to increasing the knowledge, expertise and skills at both undergraduate and postgraduate level, of primary care providers to strengthen their capacity for assessment, diagnosis, treatment and referral of people with mental health problems and mental disorders.

\section{The contemporary nature of mental health nursing}

All forms of nursing are concerned with the positive and negative variables impacting on a person's life. It is generally well-established that nursing across the lifespan involves high levels of communication and understanding. In psychiatric-mental health nursing, however, the field is highly charged by the interpersonal, emotional and dynamic processes of human experience. It is where ethical issues pervade each and every aspect of care (Christensen, 1997; Campbell et al, 1997). Psychiatric-mental health nurses are chiefly concerned with helping people heal, cope and come to terms with situations marked by the twin processes of physical and emotional distress, disturbance and breakdown. The psychiatric-mental health nurse is a person with a high level of skill and knowledge to effectively manage the complex nomenclature of the often challenging and multi-dimensional aspects of human behaviour (Regan-Kubinski, 1995; Doyle, 1996; Woods, 1996).

\section{How the mentally ill are portrayed}

Psychiatric-mental health care poses special considerations that are a little different from those in other areas of nursing. The most substantial factor relevant to and intersecting with the topic of this paper, is the way people view others with a mental health problem and/or difficulty. People with a mental illness suffer not only from the problem affecting their mental faculties, but also how they are perceived by those around them. 
Consider, for example, the following recent international references to the mentally ill in the print media: "Mentally ill man dies in custody" (Gunn, 1994); "Mental health a disgrace: Burdekin" (Clausen, 1994); "Shootings of mentally disturbed; police face questions" (Pegler et al, 1994); "Mentally ill Aboriginal patients kept in wire cages" (Kennedy \& Hammond, 1992) and "Killings prompt mental care review" (Laurance, 1993). Lenore Nicklinwriting in The Bulletin magazine (April 1992) described a man whose illness caused him to take the life of three people, as "one of those schizophrenics (with) the classic disease of madness". The print headline to this article read in capital block letters, "ILLNESSTHATBREEDSKILLERS".

These reports raise problems above and beyond any particular mental health problem, by incorporating issues of perception and attitude towards the mentally ill. Careful scrutiny of these media reports reveals careless use of language engendering fear, antipathy and ignorance towards the notion of mental illness and people who suffer from it. A message, both explicit and implicit, of fear, mistrust and suspicion towards such people who are portrayed as something less than human and certainly "out of control". General nurses themselves speak of the media as "truthfully" informing them that the mentally ill are untrustworthy, sinister and foreboding beings (Procter \& Hafner, 1991). The author considers this to be a damning indictment of stereotypic reporting of the mentally ill by a media so powerful, its social function so profound, they have been called the "consciousness industries", because they sell ways of thinking, ways of seeing, ways of talking about the world (Cunningham \& Turner, 1993:5).

Unfortunately, the health professions, mainly nursing and medical, have not always been of help in the education of the public about psychiatric mental health care and treatment. The tragic events at Chelmsford, a small private hospital in the north-western suburbs of Sydney during the 1960's and 1970 's, bears testimony to this. There, a large number of patients were treated with so called deep sleep "therapy", often in combination with Electro Convulsive Therapy. Over 1000 patients were treated this way, 24 of whom died; one third of whom were aged under 50 . Others suffered brain damage, convulsions, cardiac irregularities, urinary tract infections, fractures and many other serious complications (Ellard, 1991). More recently, it was reported that a senior nurse at South Australia's Glenside Hospital, a major psychiatric in-patient treatment centre, rammed a patient with a wheelchair, dragged him in a headlock and left him to lie on the floor in a pool of urine (Clark, 1997).

As a consequence of these actions it cannot be over emphasised how important it is that clinicians and educators work towards helping nurses obtain and maintain an optimum level of understanding and compassion for people with psychiatric problems. Aligned with this is the need for clinical nurses who are specifically educationally prepared to work with the mentally ill to participate in this process.

\section{EDUCATION TO IMPROVE UNDERSTANDING}

Taking the above information into thoughtful consideration, progress can be made to help nurses to improve their understanding and compassion for people with a mental illness. In the author's work as a clinical lecturer in psychiatric-mental health nursing for third year, general nursing students enrolled in a three year Bachelor of Nursing program at the University of South Australia, a program which was specifically developed to help students care for the mentally ill. In particular, to better inform nurses of how negative, stereotypic and traditional attitudes towards the mentally ill and psychiatric hospitals, can be problematicin practice. In the next section the educational program will be summarised.

\section{The Program'}

This educational program, briefly summarised, comprised of theoretical and practical elements:

$¥ \quad$ Theoretical education by lecture and tutorial about the major categories of mental illness and their multidisciplinary treatment options ( 8 hours).

$¥ \quad$ Two weeks of supervised clinical field experience in a major adult public psychiatric teaching hospital (80 hours). This two week clinical placement is punctuated by tutorials and debriefing style-meetings with clinicians to help learners situate their experience in its wider context.

$¥$ A workshop/seminar on the perceived benefits of clinical practice and integration of prior learning for future practice ( 8 hours).

Up to twenty five students participate in the program. The program was developed in direct reference to worldwide changes in mental health care and the following fundamental beliefs. Firstly, the belief that the way nurses relate to patients who are distressed and disturbed, is greatly influenced by how they perceive them. Secondly, as Fitzpatrick et. al. (1993:1493) argue, the belief that collaboration between the University sector and clinicians is essential "to meet the learning needs of students and best improve their knowledge base" .These beliefs led to the development of the program by both clinicians and educators that afforded an opportunity to cross-fertilise their ideas and expertise. Castledine (1993) and Coulter (1990) strengthen the case for clinicians and academics coming together this way by arguing that careful planning inevitably excites both the reflective and productive qualities of the nurse.

This last point is an important one for the following reasons. As existing psychiatric-mental health nurses are afforded an opportunity whereby they feel that their practical skills and knowledge can be used as a resource for course planners, there may be a tendency for them to participate in the program with a sense of valued and shared involvement. With a sense of valued involvement in contemporary nursing education and practice, comes a sense of belonging to the aims and objectives of professional practice. Such involvement is important as it further serves to build an educational program from the "bottom up" rather than "top down".

Aligned with these beliefs, the program used a combination of seminars, lectures and tutorials as appropriate learning strategies. As Coulter (1990) posits, the dynamic blend of humanistic and behavioural learning models offers the

\section{Footnote}

' Full details of the program, including student recommended readings and study assignment questions are freely available from the author. 
opportunity for learners to engage in self directed learning that is not only qualitatively meaningful but it also accommodates flexibility during times of change and unfamiliarity.

\section{Journal Writing}

An important part of the educational process for students was their use of the reflective journal. To help students with this process, the coordinator introduces journal use by self disclosing contents of a similar reflective work experience. Each student is given a copy of Procter's (1992) short text Managing a Difficult Client: An Insight Orientated Approach, to read with a view to seeing how this example of journal writing was used to strengthen clinical practice. It was posited by the teaching staff that particular attention should be given by students to their exploring and explicating whether or not "first hand" experiences in working with the mentally ill changed their pre-conceived understanding of this group. All students were strongly encouraged to write in their journals about this and any other issue they thought important in their nursing journey.

This means that the reflective journal was a place to record a running account of experiences, ideas, thoughts and feelings during clinical experience. The reflective journal was encouraged as the place for students to work through personal and subjective responses to clinical situations, and to recognise the development of practice (Street, 1991). Students were alsoencouraged to see the reflective journal as an invaluable learning record that they may wish to keep for many years. That is, a place for life-long learning and the formulation of thoughts and opinions (Atkins \& Murphy, 1993). More than anything else, it was posited that when students come to write and reflect in their journal, there could be a constant interplay between personal, professional, spiritual and emotional material on the one hand, and intellectual growth on the other. That is, a fascinating insight into what it means to be a student nurse in a mental health setting, what is particular about that meaning, and what this implies for future practice.

Reflective journal writing has proved an invaluable means to help students make sensitive revisions of their understanding of this specialty area. With eyes more widely open to the complex ways that behavioural and interpersonal issues are at play in psychiatric-mental health nursing, such understandings become an intregal part of one's practice. They define not only the discourse of the student, but her or his literal position in relation to patients both present and future.

\section{Program Results}

Using qualitative and quantitative research approaches, it has been revealed that the clinical fieldwork component of this program was a worthwhile, positive experience which engendered positive attitudes towards them of a kind that seem likely to persist (Procter \& Hafner, 1991; Procter, 1995). After spending two weeks with these patients, a large majority (more that $75 \%$ ) of students showed a significant shift from traditional to contemporary views about how the mentally ill should be related to, cared for and treated. Students who participated in the program frequently reported that:

"Before clinical placement, I was scared about coming to the hospital. Mainly because of what I'd seen on TV'. 'I now realise that mental illness is an illness like any other'. 'These people need understanding and support, more than anything else'. 'I now feel more confident about approaching people with a psychiatric illness'. I can't believe what the staff have to do for the patients, and they were so good to us. Where is the support for them?"

In addition to these findings, psychiatric-mental health nurses themselves were shown to be invaluable in assisting learners to overcome stereotypic views of the mentally ill as sinister, dangerous, and foreboding beings. This knowledge has been useful in its own right and will also serve to illustrate an important reference point for course planners of undergraduate and graduate nurse programs. Direct contact with staff and patients in mental health settings was an enjoyable one for most of the nurses who participated in the program, and it was further shown to engender positive attitudes towards the mentally ill of a kind that seem likely to exist.

Overall the general nursing students experience of working in a psychiatric setting helped de-stigmatise mental illness and the mentally ill. On this basis it is anticipated that as general nurses, students may be able to act more thoughtfully and tactfully during nurse-patient interaction. As all nurses are destined at some time in their career to provide care for a mentally ill person, first hand experience in a supportive educational environment is an important part of the preparation required to do this.

\section{CONCLUSION}

This article has described the role of the mental health component of a general nurse's education as one that engenders positive attitudes towards the mentally ill of a kind that seems likely to persist. If these experiences have touched the lives of learners, general nurses will be able to respond appropriately and sensitively to the needs of people with mental health difficulties in general wards of general hospitals. Over time, it is hoped that much can be written about the inadequate care of these people to date (see for example Rentoul et al, 1991). Moreover, academics and clinicians with expertise in and dedication to mental health nursing should be encouraged by their academic colleagues to help students better assess, relate to, and comfort people with mental distress: a feature of care in all practice settings.

Perhaps the challenge ahead is for nursing programs leaders outside of the psychiatric-mental health area eg. Coronary Care Nursing; Obstetric Nursing; Perioperative Nursing; Aged Care Nursing, (to name just a few), to engage in teaching and guidance from their clinical and academic psych-mental health nursing colleagues, so that clinically relevant student experiences can be developed. After all, people with mental illness do suffer from heart disease, have children, need surgical operations and grow old.

\section{BIBLIOGRAPHY}

ATKINS, S \& MURPHY, K 1993: Reflection: a review of the literature. Journal of Advanced Nursing, 18(8):1188-1192.

CAMERON, B \& MITCHELL, A 1993: Reflective peer journals: developing authentic nurses. Journal of Advanced Nursing. 18(2):290297.

CAMPBELL, A; CHARLESWORTH, M; GILLETT, G \& JONES, G 1997: Medical Ethics. Auckland: Oxford University Press.

CASELDINE, G 1993: Warning: some courses can damage your education. British Journal of Nursing. 2(17):873-4.

CHRISTENSEN, R 1997: Ethical issues in community mental health: cases and conflicts. Community Mental Health Journal, 33(1):5-11.

CLARK, F 1997: Nurse 'dragged patient on floor'. The Advertiser, June 12.

CLAUSEN, L 1993: Mental health a 'disgrace'. The Advertiser, October 21. 
COULTER, M 1990: A review of two theories of learning and their application in the practice of nurse education. Nurse Education Today, 10(2):333-338.

CUNNINGHAM, S \& TURNER, G 1993: The Media In Australia. Sydney: Allen and Unwin.

DOYLE, M 1996: Assessing risk of violence from clients. Mental Health Nursing, 16(3):20-23

ELLARD, J 1991: Chelmsford and its aftermath. Psychiatric Bulletin, 15(6):686-688.

FITZPATRICK, J; WHILE, A \& ROBERTS, J 1993: The relationship between nursing and higher education. Journal of Advanced Nursing, 18(9):1488-1497.

GUNN, M 1994: Coroner slams officer training. The Advertiser, Jan 5.

KENNEDY, F \& HAMMOND, J 1992: 25 in cells that contravene torture convention: Burdekin. The Australian, Dec: 11 .

LAURANCE, J 1993: Killings prompt mental care review. The Times, July 3 .

LEAR, G 1993: Managing care at home. Nursing Times, 89(5):2627.

MACIAS. C; KINNEY R; FARLEY, W; JACKSON R \& VOSS, B 1994: The role of case management within a community support system; partnership with psychosocial rehabilitation. Community Mental Health Journal, 30(4):323-339.

Mc CRONE, P; BEECHAM, J \& KNAPP, M 1994: Community psychiatric nurse teams: cost-effectiveness of intensive support versus generic care. British Journal of Psychiatry, 165(4):218-221.

NATIONAL MENTAL HEALTH POLICY 1992: Australian Health Ministers Conference: Australian Government Publishing Office.

PEGLER, T; SAUNDERS, D \& MILBURN, C 1994: Shootings: police face questions. The Age, Jan 5.

PROCTER, NG 1992: Managing a difficult client: an insight orientated approach. Contemporary Nurse, I(1):43.

PROCTER, NG 1995: Art and reflective practice: experiences from students in mental health nursing. (In: Woodhams, L \& Bishop, M eds. 1995: The arts in health: exploring the role of the arts in health. Cunningham Centre, Queensland Health Darling Downs Regional Health Authority Central Sector: 50-61).

PROCTER, NG \& HAFNER, RJ:1990 The exploration of general nursing student attitudes and perceptions towards mentally ill patients and psychiatric hospitals. Australian Journal of Adult and Community Education, 30(3):191-192.

PROCTER, NG \& HAFNER, RJ 1991: Student nurses attitudes to psychiatry: the influence of training and personality Journal of Advanced Nursing, 16(7):845-849.

REGAN-KUBINSKI, MJ 1995: Judgement tasks in clinical psychiatric mental health nursing. Perspective's in Psychiatric Care, 31(3):20-24.

RENTOUL, L; NORMAN, I \& RITTER, S 1991: The mental health component of a general nursing curriculum a critical review of English National Board guidelines. Nurse Education Today, 11(6):1029-1039.

STREET, A 1991: From image to action: reflection in nursing practice. Victoria: Deakin University Press.

WOODS, P 1996: How nurses make assessments of patient dangerousness. Mental Health Nursing, 16(4):20-22.
BOOK REVIEW - BOOK REVIEW - BOOK

\section{Person- centred communication} Theory and Practice 1998

Dries du Toit, Hanka Grobler and Rinie Schenk

The authors are from the University of South Africa, Dries du Toit holds a D. Phil from the University of Port Elizabeth. Hanka Grobler lectures in Family Therapy and Casework at UNISA and has a MA in Counselling Psychology from the same university. Rinie Schenk lectures in Participatory Development and Casework at the University of South Africa and has a MA in Social Work from the University of Pretoria and a MA SS (Mental Health) from UNISA.

Person-centred communication offers helping professionals an understanding of the theory, practice, and value base that underline a person- centred approach in helping people. It is a in depth discussion of a person- centred manner about people (individuals, groups and communities).

The book is divided into five sections, with the underlining proposition that in interaction with others, the self is formed:

* Section A: Theory - Thinking about people.

This section is based on the person centred approach of Carl Rogers with the focus on Rogers' nineteen propositions each of which deals with a specific aspect of a person's and facilitator's functioning in seven chapters.

* Section B: The facilitator's values.

In these next four chapters the values of respect (mutual), individualisation, self-determination and confidentiality are discussed.

* Section C: Putting thinking and values into practice: Dealing with symbolised experiences.

In the next three chapters attentiveness,

listening and empathy are discussed.

* Section D: Putting thinking and values into practice: Dealing with unsymbolised experiences.

Advanced empathy and immediacy are dealt with in the next two chapters.

* Section E: Some special considerations.

The focus in the final three chapters is on cross-

cultural communication, people in conflict and the self of the facilitator.

Whereas it could be a short-coming that the book is written from one frame of reference, I found it extremely well written and useful as I believe that Rogers' theory is a basis for developing effective communication skills as a facilitator. Of extreme use, are the wonderful examples used throughout the book to enhance and explain what is described.

AntoinetteGmeiner, R.N.,D.Cur Senior Lecturer Department of Nursing Science Rand Afrikaans University 